\title{
AnNA FALKOWSKA
}

Uniwersytet Mikołaja Kopernika w Toruniu

\section{OCHRONA KONSUMENTA NA PRZEŁOMIE EPOK - INSTYTUCJA RĘKOJMI W PRAWIE NAJNOWSZYM}

Prawo ochrony konsumenta stanowi obecnie ważną część prawa cywilnego, intensywnie rozwijającą się w drodze implementacji licznych dyrektyw europejskich ${ }^{1}$. Ochrona konsumenta ma jednak długą tradycję sięgającą swymi korzeniami czasów prawa rzymskiego. Jednym z najważniejszych praw konsumenta jest prawo do należytej jakości świadczenia. Podstawową instytucją prawną, mającą na celu zabezpieczenie tego prawa jest rękojmia. Również instytucja rękojmi swoją genezę wywodzi z prawa rzymskiego².

W prawie polskim sama nazwa „rękojmia” dla określenia instytucji ochrony nabywcy przed nienależyta jakością świadczenia, pojawiła się stosunkowo późno. Dopiero w XIX w. powstaje określenie „rękojmia za wady" w dzisiejszym tego słowa znaczeniu ${ }^{3}$. W dawnym prawie sądowym odpowiedzialność za wady ujęta była w instytucji ,zastępuewikcji”4. Zwrot „rękojmia” w okresie przedrozbiorowym natomiast miał zupełnie odmienne znaczenie ${ }^{5}$.

${ }^{1}$ Por. E. ŁęTowska, Prawo umów konsumenckich, Warszawa 2002.

2 W. Bojarski, Prawo rzymskie, Torun 1999, s. 189-190; W. Rozwadowski, Prawo rzymskie. Zarys wykładu wraz z wyborem źródet, Poznań 1992, s. 177-178.

3 Z.K. NowaKowski, Ochrona nabywcy rzeczy z wadami, «RPEiS» 29.2/1967, s. 4.

4 J. Matuszewski, Ewikcja i rękojmia, «CPH»15.2/1963, s. 126-127.

${ }^{5} \mathrm{~W}$ przedmiocie pojęcia rękojmi $\mathrm{w}$ dawnym prawie polskim zob. P. DĄBKowsKI, Rękojemstwo w prawie polskim średniowiecznem, Lwów 1904; J. MATUsZewsKi, 
Ewolucję instytucji rękojmi w najnowszym prawie polskim możemy podzielić na kilka etapów. Pierwszy etap przypada na lata 1918-1934. Rok 1918 oznacza odzyskanie niepodległego bytu przez Rzeczypospolitą Polską po ponad stuletnim okresie zaborów. Z tą też datą stało się możliwe przygotowywanie i wprowadzanie rodzimych regulacji prawnych. Z dniem 1 lipca 1934 r. wszedł w życie kodeks zobowiązań uchwalony rok wcześniej ${ }^{6}$.

W wyżej wskazanym okresie instytucję rękojmi normowały przepisy dzielnicowe: kodeks cywilny niemiecki (BGB) z 1896 r., kodeks cywilny austriacki (ABGB) z 1811 r., Kodeks Napoleona z 1804 r. oraz t. X cz. 1 Zwodu Praw Cesarstwa Rosyjskiego ${ }^{7}$. Każda z tych regulacji opierała się na nieco odmiennych zasadach. Przed członkami powołanej w 1919 r. Komisji Kodyfikacyjnej stanęło w związku z tym trudne zadanie ujednolicenia przepisów wywodzących się z różnych kultur i systemów prawnych. W takcie prac kodyfikacyjnych zwyciężył dominujący pogląd, że polski kodeks zobowiązań powinien być etapem rozwojowym prawa dotychczas obowiązującego na ziemiach polskich $^{8}$. Stanowić więc miał swego rodzaju kompromis między niekiedy sprzecznymi - systemami kodeksu Napoleona oraz austriac-

Rękojmia $w$ rozumieniu Kodeksu Zobowiazań i rękojmia $w$ dawnej polszczyźnie, «CPH» 15.1/1963, s. 203-222.

${ }^{6}$ Rozporządzenie Prezydenta Rzeczypospolitej Polskiej z dnia 27 października 1933 r. - Kodeks zobowiązań (Dz.U. Nr 82, poz. 598).

7 Pomijam w niniejszym artykule kwestię prawa węgierskiego, które obowiązywało do 25 listopada 1922 r. na przyłączonych do Polski niewielkich obszarach północnego Spisza i górnej Orawy. W dziedzinie prawa cywilnego prawo to w większości nie zostało skodyfikowane. Na ten temat zob. więcej: J. CIĄGWA, Recepcja prawa wegierskiego na Spiszu i Orawie po roku 1920, «Studia Historyczne» 2/1996, s. 199-222; TENŻE, Stan prawny na Spiszu i Orawie w latach międzywojennych, «Studia Iuridica Silesiaca» $11 / 1986$.

${ }^{8} \mathrm{Na}$ temat innych koncepcji unifikacji i kodyfikacji prawa zobowiązań w II Rzeczypospolitej zob. J. Glass, Problemat ustawodawstwa cywilnego w województwach wschodnich, «Gazeta Sądowa Warszawska» 24/1924, s. 360-361 oraz TENŻE, Ustawodawstwo cywilne w okręu białostockim, «Gazeta Sądowa Warszawska» 18/1925, s. 282; F. Zoll, Polski kodeks cywilny, odbitka z «Przeglądu Współczesnego» 87/1929, s. 4. 
kiego i niemieckiego kodeksu cywilnego9. Uważano, iż dzięki temu założeniu wprowadzi się kodeks bez większych trudności we wszystkich częściach państwa, tak aby mieszkańcy żadnej dzielnicy nie mieli wrażenia, że narzuca się im prawo innej dzielnicy ${ }^{10}$.

Połączenie tych często różnych koncepcji nie było zadaniem łatwym, jednakże członkowie Komisji Kodyfikacyjnej wywiązali się $\mathrm{z}$ niego doskonale, tworząc dzieło $\mathrm{z}$ jednej strony oryginalne, $\mathrm{z}$ drugiej niezwykle nowoczesne. Udało im się bowiem w sposób twórczy połączyć rozwiązania wywodzące się z różnych ustawodawstw, jednocześnie przejmując do kodeksu zobowiązań najbardziej wartościowe regulacje.

Wejście w życie kodeksu zobowiązań rozpoczęło nowy etap w rozwoju instytucji rękojmi w polskim prawie. Regulacje kodeksu zobowiązań w przedmiocie odpowiedzialności sprzedawcy wzorowane były w największym stopniu na niemieckim kodeksie cywilnym oraz szwajcarskim prawie obligacyjnym ${ }^{11}$. Z prawa niemieckiego przejęto konstrukcję sprzedaży według próbki lub wzoru ${ }^{12}$, uregulowanie od-

${ }^{9}$ R. LONGCHAMPS DE BERIER, Zjednoczenie prawa obligacyjnego $w$ państwach słowiańskich. Referat główny, odbitka z «Przeglądu Prawa i Administracji», Lwów 1933, s. 8.

10 Tamże, s. 8.

${ }^{11}$ Autorka przebadała jedynie drobny wycinek kodeksu zobowiązań normujący odpowiedzialność sprzedawcy za wady fizyczne.Poczynione przezniąustaleniaznajdują jednak potwierdzenie w analizie całości unormowania, której dokonał L. Górnicki stwierdzając, iż twórcy kodeksu zobowiązań starali się „znaleźć rozwiązania godzące ze sobą oba systemy - francuski i germański. To dążenie do zachowania równowagi pomiędzy Kodeksem Napoleona i francusko-włoskim projektem kodeksu zobowiązań i umów z jednej strony, a z drugiej zwłaszcza prawem szwajcarskim i niemieckim, widoczne było przede wszystkim w części ogólnej kodeksu, którą współtworzył Domański. Natomiast część szczegółowa, którą przygotowali Longchamps i Till, wykazywała o wiele wyraźniejsze inspiracje systemem germańskim.” (L. GóRNICKI, Prawo cywilne w pracach Komisji Kodyfikacyjnej Rzeczypospolitej Polskiej w latach 1919-1939, Wrocław 2000, s. 469).

12 Por. § 494 BGB. Zob. także: Komisja Kodyfikacyjna. Podkomisja prawa o zobowiązaniach, Uzasadnienie projektu kodeksu zobowiazań z uwzględnieniem ostatecznego tekstu kodeksu w opracowaniu głównego referenta projektu Prof. Romana Longchamps de Berier, z. 7, art. 294-369, Warszawa 1937, s. 50; L. DomaŃSKI, 
powiedzialności za wady zwierząt ${ }^{13}$, unormowanie odpowiedzialności za obszar (jednakże w tym zakresie wzięto także pod uwagę rozwiązania francuskie i szwajcarskie) ${ }^{14}$. Na BGB wzorowane było również rozwiązanie, zgodnie z którym jeśli nabywca zawiadomił sprzedawcę o wadzie, sprzedawca mógł wyznaczyć kupującemu odpowiedni termin do oświadczenia, czy zamierza odstąpić od umowy ${ }^{15}$. Po upływie tego terminu odstapienie było już niedopuszczalne.

Odzwierciedleniem wpływów prawa szwajcarskiego w kodeksie zobowiązań było rozszerzenie katalogu uprawnień nabywcy o żądanie wymiany $^{16}$. Również za wzorem szwajcarskiego Code des Obligations przyznano nabywcy szczególne prawa, ale też nałożono dodatkowe obowiązki, w przypadku ujawnienia wady rzeczy nadesłanej z innej miejscowości ${ }^{17}$. Ponadto na podstawie regulacji szwajcarskiej ukształtowano skutki odstapienia od umowy sprzedaży oraz wprowadzono

Instytucje kodeksu zobowiqzań. Komentarz teoretyczno-praktyczny. Część szczególna, I, Warszawa 1938, s. 67; J. NAmITKIEWICz, Kodeks zobowiazań. Komentarz dla praktyki opracowany przy wspóludziale Alfreda Smolińskiego, II, Łódź 1949, s. 37.

13 Por. § 481-492 BGB oraz rozporządzenie cesarskie z dnia 27 marca 1899 r. o wadach głównych i czasokresach rękojmi w handlu bydłem (Dziennik Urzędowy Rzeszy, s. 219).

14 Por. § 468 BGB, art. 219 szwajcarskiego kodeksu zobowiązań oraz art. 16171620 kodeksu Napoleona.

15 Por. $§ 466$ BGB.

16 Por. art. 206 szwajcarskiego kodeksu zobowiązań. Spośród przepisów dzielnicowych jedynie BGB przyznawał nabywcy uprawnienie do żądania wymiany rzeczy wadliwej na rzecz wolną od wad. Kodeks cywilny niemiecki przewidywał to roszczenie tylko wówczas, gdy przedmiotem sprzedaży była rzecz oznaczona co do gatunku. Kodeks zobowiązań przyznawał natomiast kupującemu analogiczne uprawnienie w sytuacji, gdy sprzedaż obejmowała rzeczy zamienne. Twórcy kodeksu zobowiązań oparli się bowiem w tym zakresie na redakcji zawartej w kodeksie szwajcarskim. Artykuł 206 szwajcarskiego kodeksu zobowiązań przewidywał roszczenie o wymianę w przypadku, gdy przedmiotem sprzedaży były rzeczy zamienne, a nie, jak stanowiło prawo niemieckie, rzeczy oznaczone co do gatunku.

${ }^{17}$ Komisja Kodyfikacyjna, Uzasadnienie projektu kodeksu zobowiazań..., s. 53. Por. także art. 204 ust. 3 szwajcarskiego kodeksu zobowiązań. 
dłuższy termin do dochodzenia praw z rękojmi w odniesieniu do wad budynku ${ }^{18}$.

Istotną zaletą szwajcarskiego kodeksu obligacyjnego z punktu widzenia unifikacji prawa w Polsce było to, iż łączył dwa systemy: germański i romański. Systemy te ścierały się również na terenie państwa polskiego stanowiącego zlepek 3 różnych zaborów. System romański obowiązywał w dawnym Królestwie Kongresowym, system germański na terenie byłego zaboru pruskiego i austriackiego. Ponadto szwajcarski kodeks zobowiązań z 1911 r. stanowił bardzo nowoczesną kodyfikację $^{19}$. Uwzględnienie przez członków Komisji Kodyfikacyjnej tego postępowego kodeksu umożliwiło odzwierciedlenie w polskim prawie zobowiązań najnowszych prądów epoki. Nowatorski charakter miało m.in. wprowadzenie do kodeksu zobowiązań obowiązku zachowania aktów staranności. Rozwiązanie to było wzorowane na najnowocześniejszych tekstach prawnych tamtego okresu: szwajcarskim kodeksie zobowiązań i projekcie francusko-włoskim ${ }^{20}$. Obowiązujące wcześniej na ziemiach polskich przepisy nakładały na nabywcę określone obowiązki w zakresie zbadania rzeczy i zawiadomienia o wadach tylko w obrocie handlowym ${ }^{21}$. Ochronę interesów sprzedawcy w obrocie mieszanym zapewniał jedynie krótszy termin dochodzenia roszczeń2 ${ }^{2}$. W świetle kodeksu zobowiązań nabywca w każdym wypadku był zobowiązany zawiadomić sprzedawcę o wadzie rzeczy, w ciągu miesiąca od jej wykrycia, w określonych sytuacjach zobligowany był także do zbadania rzeczy ${ }^{23}$. Rozwiązanie powyższe umożliwiało sprzedaw-

18 Por. art. 209 i 219 ust. 3 szwajcarskiego kodeksu zobowiązań.

19 S. Posner, Prace Komisji Kodyfikacyjnej. Kilka uwag z powodu sprawozdania prezydenta K.K. profesora Fiericha, «Gazeta Sądowa Warszawska» 9/1924, s. 118, stwierdził w 1924 r., że jest to najlepszy z istniejących ówcześnie kodeksów.

${ }^{20}$ L. Domański, Instytucje..., s. 73; A. SzPUnAR, Roszczenia z tytułu rękojmi za wady fizyczne, «CPiE»1/1945, s. 23.

21 A. SzPunar, Roszczenia z tytułu rękojmi..., s. 23.

${ }^{22}$ Komisja Kodyfikacyjna, Uzasadnienie projektu kodeksu zobowiazań..., s. 50.

${ }^{23}$ Art. $324 \S 1$ k.z. 
cy sprawdzenie czy wada rzeczywiście istniała i jakie przyczyny spowodowały jej wystapienie.

Mniejszy wpływ na kształt instytucji rękojmi w kodeksie zobowiązań wywarły przepisy austriackiego kodeksu cywilnego oraz kodeksu Napoleona $^{24}$. Jest to o tyle zaskakujące, iż były to regulacje najbliższe głównym twórcom kodeksu zobowiązań. E. Till i R. Longchamps de Berier - autorzy projektu głównego części szczególnej prawa o zobowiązaniach - byli profesorami Uniwersytetu Jana Kazimierza we Lwowie, prowadzili badania naukowe oraz pracę dydaktyczną w obrębie kultury prawnej ABGB. Adwokat L. Domański praktykował w Warszawie, na obszarze obowiązywania kodeksu Napoleona. Okazało się jednak, iż członkowie Komisji Kodyfikacyjnej potrafili odrzucić rodzime przyzwyczajenia i oprzeć się na regulacjach najlepiej zabezpieczających interes obu stron umowy sprzedaży.

Jak wyżej wskazano, prace nad kodeksem zobowiązań oparte zostały na szerokiej bazie źródłowej. Oprócz kodeksów dzielnicowych i wspominanego już szwajcarskiego kodeksu zobowiązań, prześledzono rozwiązania przyjęte $\mathrm{w}$ wielu innych ustawodawstwach, m.in. w kodeksie serbskim, portugalskim czy kodeksie japońskim ${ }^{25}$. Pod uwagę brano nie tylko obowiązujące przepisy innych państw, ale także projekty nowych regulacji $\mathrm{w}$ zakresie prawa obligacyjnego $\mathrm{np}$. projekt francusko-włoski, projekt rosyjski czy węgierski. Kodeks zobowiązań nie był jednak powieleniem żadnej z ówcześnie obowiązujących regulacji, lecz efektem twórczych badań członków Komisji

${ }^{24}$ Za wzorem ABGB uregulowano w kodeksie zobowiązań m.in. ograniczenie dochodzenia roszczeń z tytułu rękojmi terminami zawitymi. Zbliżone rozwiązanie przewidywał również francusko-włoski projekt kodeksu zobowiązań i umów. Na tymże projekcie oraz na kodeksie Napoleona wzorowana była, wprowadzona do k.z., możliwość umownego rozszerzenia, ograniczenia bądź wyłączenia odpowiedzialności z tytułu rękojmi. W oparciu o te przepisy wprowadzono zastrzeżenie, iż wyłączenie lub ograniczenie odpowiedzialności było nieważne, jeśli sprzedawca zataił podstępnie wadę przed kupującym.

${ }^{25}$ Regulacje kodeksu japońskiego były analizowane m.in. przy tworzeniu przepisów dotyczących terminu do dochodzenia uprawnień z tytułu rękojmi (E. TILL i R. Longchamps de Berier, Projekt prawa o zobowiazaniach (część szczegółowa), odbitka z «Przeglądu Prawa i Administracji» 1928, s. 177). 
Kodyfikacyjnej, polegających na pogłębionej analizie prawnoporównawczej, prowadzącej w konsekwencji do wybierania rozwiązań najlepiej dostosowanych do istniejących wówczas warunków obrotu. Rozwiązania te następnie modyfikowano w sposób najbardziej odpowiadający zasadzie słuszności, tak aby wyważyć interesy zarówno sprzedawcy, jak i kupującego ${ }^{26}$.

Kodeks zobowiązań stanowił kolejny krok w ewolucji instytucji rękojmi - oprócz uprawnień wywodzących się ze skarg edylskich, wprowadzał możliwość żądania przez kupującego wymiany towaru

${ }^{26}$ Jako przykład twórczej pracy głównych referentów k.z. może służyć artykuł 30 projektu głównego części szczególnej prawa o zobowiązaniach autorstwa E. Tilla i R. Longchamps de Berier. Analizując obowiązujące na ziemiach polskich ustawy cywilne, autorzy zwrócili uwagę, iż nie nakładały one na nabywcę obowiązku bezzwłocznego zawiadomienia sprzedawcy o wadzie i wprowadzały dla ochrony sprzedawcy jedynie krótszy termin przedawnienia. W ocenie jednak E. Tilla i R. Longchamps de Berier z samej istoty instytucji rękojmi wynikało, iż należy ją stosować z najdalej idącym uwzględnieniem interesów sprzedawcy, gdyż odpowiadał on niezależnie od winy. W interesie sprzedawcy natomiast było dowiedzenie się o wadzie i wynikających z niej roszczeniach nabywcy jak najszybciej - czy w celu przygotowania się do obrony czy też w celu wykorzystania rzeczy w inny sposób. $Z$ tych względów referenci główni wzięli pod uwagę rozwiązania bardziej nowoczesne - zawarte w kodeksie szwajcarskim, który nakładał na kupującego obowiązek zbadania rzeczy i niezwłocznego zawiadomienia sprzedawcy o wadach, które ujawniły się w trakcie badania rzeczy, bądź wyszły na jaw później (art. 201). Autorzy projektu głównego doszli jednak do wniosku, iż prawo szwajcarskie w zbyt dalekim stopniu chroni interesy sprzedawcy, gdyż zostało stworzone przede wszystkim dla zabezpieczenia obrotu gospodarczego. W obrocie powszechnym natomiast, obowiązek niezwłocznego zbadania rzeczy pod groźbą utraty praw z tytułu rękojmi byłby zbyt uciążliwy i w konsekwencji prowadziłby do unicestwienia słusznej ochrony kupującego. Ponadto nawet $\mathrm{w}$ obrocie gospodarczym nie zawsze zbadanie nadesłanego towaru było praktykowane np. jeżeli towar był przeznaczony do dalszej odsprzedaży w tym samym opakowaniu jak np. wino. W konkluzji referenci główni doszli do wniosku, iż tylko dwie zasady „odpowiadają słuszności i czynią zadość uzasadnionym interesom obu stron": po pierwsze, iż nabywca powinien zawiadomić sprzedawcę natychmiast po wykryciu wady; po drugie, iż na kupującym ciąży obowiązek zbadania rzeczy tylko w tych wypadkach, w których badanie rzeczy w normalnym toku czynności jest praktykowane i wskazane (E. Till i R. LongChamps De Berier, Projekt prawa o zobowiazaniach..., s. 171). 
na niewadliwy ${ }^{27}$. Z uprzednio obowiązujących na ziemiach polskich kodeksów, jedynie BGB przyznawał nabywcy uprawnienie do żądania dostarczenia zamiast rzeczy wadliwych takiej samej ilości rzeczy wolnych od wad $^{28}$. Nastapiło tym samym wzmocnienie pozycji prawnej kupującego: uprawnienia o rzymskim rodowodzie pozwalały jedynie na przywrócenie zakłóconej wskutek wadliwości rzeczy ekwiwalentności świadczeń obu stron umowy. Dzięki uprawnieniu do żądania wymiany nabywca mógł natomiast uzyskać nowe, niewadliwe świadczenie.

Przepisy o odpowiedzialności z tytułu rękojmi zostały ukształtowane w kodeksie zobowiązań jako przepisy iuris dispositivi. Strony mogły przez umowę odpowiedzialność z tytułu rękojmi rozszerzyć, ograniczyć lub wyłączyćc ${ }^{29}$. Takie umowne wyłączenie lub ograniczenie odpowiedzialności nie było jednak ważne, jeśli sprzedawca zataił podstępnie wadę przedmiotu sprzedaży przed kupującym. Przepisy o rękojmi odzwierciedlały w tym zakresie dwie istotne zasady kodeksu zobowiązań: zasadę swobody umów oraz zasadę uczciwego obrotu ${ }^{30}$.

27 Przyznanie kupującemu tego prawa, spotkało się $\mathrm{z}$ aprobatą $\mathrm{w}$ doktrynie. H. Berman, Kilka uwag do przepisów kodeksu zobowiqzań o rękojmi i błędzie, «Przegląd Sądowy» 8/1934, s. 239 uznał powyższe rozwiązanie za „znaczny postęp”, zwłaszcza w porównaniu z prawem austriackim.

${ }^{28}$ Por. przypis 15.

29 Art. 308 k.z.

${ }^{30}$ Por. J. Korzonek, I. Rosenbluth, Kodeks zobowiqzań. Komentarz, Kraków 1934, s. 685; J. Namitkiewicz, Kodeks zobowiqzań..., s. 26; L. PeiPer, Kodeks zobowiqzań, Kraków 1934, s. 409. Znaczenie tej drugiej zasady podkreślał dość silnie zwłaszcza R. Longchamps DE BerIER, Zasady kodeksu zobowiqzań, «RPRiS» 1/1934, s. 77, który stwierdził, iż „Nowoczesne prawo zobowiązań musi być wypadkową dwóch, krzyżujących się i wzajemnie się ograniczających myśli prawodawczych. $\mathrm{Z}$ jednej strony, jako prawo obrotowe, powinno dawać pewną i silną ochronę interesów jednostek, biorących udział w obrocie prawniczym, z drugiej strony, jak każde prawo, powinno mieć zawsze dobro całego społeczeństwa na oku i nie tylko nie dopuszczać, by zobowiązania stały się środkiem wyzyskiwania i krzywdzenia drugich, lecz nawet starać się o to, aby i one spełniały, w miarę możności, rolę lekarstwa na pewne patologiczne stany w stosunkach między ludźmi. Wpływem pierwszej z tych myśli prawodawczych jest zasada bezpieczeństwa obrotu i zasada ochrony zaufania w obrocie. Wpływem drugiej z tych myśli jest zasada uczciwości 
Dochodzenie uprawnień z tytułu rękojmi podlegało ścisłemu ograniczeniu terminami zawitymi. Jak wskazał R. Longchamps de Berier: „Formę tę uznano za odpowiedniejszą od formy przedawnienia, gdyż interesowanym jest także porządek prawny w tym, aby stosunki prawne, wynikające $\mathrm{z}$ umów, były możliwie rychło wyjaśnione i nie dawały po upływie dłuższego czasu powodów do procesów, w sprawach o rękojmię zwykle dość zawiłych"31. Roszczeń z tytułu rękojmi za wady fizyczne nie można było dochodzić sądownie po upływie roku, a w przypadku wad budynku po upływie pięciu lat, licząc od dnia otrzymania rzeczy przez kupującego ${ }^{32}$.

Regulacje kodeksu zobowiązań o odpowiedzialności sprzedawcy z tytułu rękojmi nie uległy zmianom w okresie II wojny światowej. Praktyka orzecznicza natomiast $\mathrm{w}$ nienormalnych warunkach wojny rozstrzygała sprawy najważniejsze i niecierpiące zwłoki. Jeśli nawet sprawy dotyczące odpowiedzialności sprzedawcy z tytułu rękojmi były przedmiotem rozstrzygnięć sądowych, to prawdopodobnie stanowiły margines rozpatrywanych spraw ${ }^{33}$.

w obrocie, uspołecznienie pewnych stosunków umownych i wyrównanie krzywd, powstających w stosunkach pozaumownych. Kodeks zobowiązań przyjął te zasady z innych współczesnych systemów prawa obligacyjnego, starając się o ile możności, przeprowadzić je jeszcze bardziej konsekwentnie i harmonijnie". Zob. także R. Longchamps de Berier, Zobowiqzania3, oprac. J. Górski, Poznań 1948, s. 465; Komisja Kodyfikacyjna, Uzasadnienie projektu kodeksu zobowiazań..., s. 36.

${ }^{31}$ Komisja Kodyfikacyjna, Uzasadnienie projektu kodeksu zobowiazań..., s. 48.

32 Art. $336 \S 1$ k.z.

${ }_{33}$ Nie sposób przytoczyć przykładów konkretnych orzeczeń sądów polskich w Generalnym Gubernatorstwie w sprawach o rękojmię ani statystyki ilościowej takich procesów. Badania utrudnia fakt, iż zachowane źródła są w znacznym stopniu niekompletne. Z ogólnych znanych dotąd ocen wynika, że w orzecznictwie tym przeważały sprawy o charakterze zobowiązaniowym i spadkowym (A. WrzYszcz, Okupacyjne sqdownictwo niemieckie w Generalnym Gubernatorstwie 1939-1945. Organizacja i funkcjonowanie, Lublin 2008, s. 106). Sądownictwo niemieckie w Generalnym Gubernatorstwie, zgodnie z powołującym je rozporządzeniem, posługiwało się m.in. przepisami niemieckiego prawa cywilnego materialnego, i to stosowanego wprost (Tamże, s. 373-374). W sprawach o rękojmię w czasach II wojny światowej na terenie Generalnego Gubernatorstwa ponownie znalazły zastosowanie przepisy BGB. Brak jednak danych o orzeczeniach sądów niemieckich w sprawach 
Również po wojnie, pomimo radykalnej zmiany stosunków społeczno-ustrojowych, kodeks zobowiązań zachował moc obowiązującą w całej rozciagłości. Możliwość zastosowania k.z. do zasadniczo odmiennych realiów gospodarczych wynikała $\mathrm{z}$ jego wysokiego poziomu legislacyjnego, a zwłaszcza elastyczności uregulowań oraz uwzględnienia w szerokim zakresie postulatu uspołecznienia prawa zobowiązań $^{34}$.

Przeobrażenia polskiej gospodarki z modelu kapitalistycznego na gospodarkę centralnie sterowana, wywarły istotny wpływ także na regulację odpowiedzialności sprzedawcy za wady. Nacjonalizacja handlu i przemysłu oraz w konsekwencji skupienie niemal całej działalności gospodarczej w rękach państwa, spowodowało wyeliminowanie konkurencji, która w stosunkach kapitalistycznych w naturalny sposób przyczyniała się do wypierania z rynku sprzedawców towarów złej jakości ${ }^{35}$. Odpowiedni poziom jakości rzeczy w państwie socjalistycznym miał natomiast zapewnić rozbudowany system aktów prawnych. W licznych wypowiedziach, zarówno naukowych jak i politycznych, podkreślano, iż z podstawowych założeń ustrojowych wynikała troska państwa socjalistycznego o jakość produkowanych i sprzedawanych przedmiotów ${ }^{36}$. Troska ta znajdowała swoje odzwierciedlenie na

o odpowiedzialność sprzedawcy za wady. Z zachowanych akt sądów niemieckich dowiadujemy się, że w orzecznictwie tych sądów dominowały sprawy z zakresu prawa rodzinnego, opiekuńczego i spadkowego (Tamże, s. 262 i 266).

34 A. StawARSKa-RiPPel, Kodeks zobowiazań w pierwszych latach Polski Ludowej, «KPP»13.3/2004, s. 701; L. GóRNICKI, Wpływ obcych ustawodawstw i doktryny prawa na polska kodyfikacje prawa prywatnego w Drugiej Rzeczypospolitej, «Zeszyty Naukowe Uniwersytetu Jagiellońskiego. Towarzystwo Biblioteki Słuchaczów Prawa. Zeszyty Prawnicze» 13/2005, s. 67; Tenże, Prawo cywilne..., s. 469.

35 M. MAdeY, Rękojmia przy dostawach w obrocie uspołecznionym w PRL, Warszawa 1965, s. 84; TENŻE, glosa do orzeczenia GKA z dnia 21 listopada 1962 r., I-5412/62, «Orzecznictwo Sądów Polskich i Komisji Arbitrażowych»1/1964, s. 45.

${ }_{36}$ M. MAdey, Rękojmia przy dostawach..., s. 75; TenżE, glosa do orzeczenia GKA z dnia 21 listopada 1962 r.; J. TopińsKi, Ogólne warunki dostaw, «PiP» 5.3/1951, s. 476; C. STAŃSKI, Jakość produkcji i oznaczanie artykułów obrotu towarowego $w$ świetle obowiqzujacych przepisów prawnych, «PUG» 8.3/1955, s. 81. Problematyka jakości produkcji została silnie zaakcentowana m.in. na IV Zjeździe PZPR (Sprawozdanie 
gruncie normatywnym m.in. w przepisach normalizacyjnych ${ }^{37}$ oraz $\mathrm{w}$ aktach z dziedziny prawa karnego ${ }^{38}$. Walce z produkcją złej jakości nadano rangę problemu ogólnospołecznego.

W tym też okresie zasadniczej zmianie uległo podejście do samej instytucji rękojmi za wady. W gospodarce kapitalistycznej punktem wyjściowym dla oceny jakości rzeczy była zawsze umowa, cel w niej oznaczony wyraźnie lub domniemany, wynikający z natury lub przeznaczenia rzeczy ${ }^{39}$. Jeśli natomiast umowa nie regulowała dokładnie kwestii jakości towaru, sprzedawca powinien świadczyć rzecz śred-

Komitetu Centralnego i wytyczne rozwoju Polskiej Rzeczypospolitej Ludowej w latach 1966-1970, «Nowe Drogi» 33.7/1964, s. 21). Nieco wcześniej problem ten został podniesiony na XXII Zjeździe KPZR, w trakcie którego podnoszono liczne postulaty dotyczące polepszenia jakości towarów (XXII Zjazd Komunistycznej Partii Zwiazku Radzieckiego. Referaty, uchwaty i przemówienia $w$ dyskusji 17.X-31.X. 1961 r., Warszawa 1962, s. 112-113, 132, 160, 172-173). Na gruncie prawa polskiego postulaty te miała realizować m.in. uchwała Nr 355 Rady Ministrów z dnia 19 września 1958 r. w sprawie zapewnienia właściwej jakości towarów przeznaczonych na zaopatrzenie ludności (M.P. Nr 77, poz. 666), która obowiązywała aż do dnia 31 stycznia 1989 r. Zob. także: pismo okólne Przewodniczącego Państwowej Komisji Planowania Gospodarczego z dnia 29 marca 1952 r. w sprawie obowiązku przestrzegania przepisów dotyczących braków i wad towarów («Biuletyn Państwowej Komisji Planowania Gospodarczego» Nr 13, poz. 81).

${ }^{37}$ Ustawa z dnia 20 grudnia 1949 r. o utworzeniu Polskiego Komitetu Normalizacyjnego oraz o polskich normach i standartach (Dz.U. Nr 63, poz. 493); dekret z dnia 4 marca 1953 r. o normach i Polskim Komitecie Normalizacyjnym (Dz.U. Nr 15, poz. 61 z późn. zm.); ustawa z dnia 27 listopada 1961 r. o normalizacji (Dz.U. Nr 53, poz. 298 ze. zm.).

38 Odpowiedzialność karną wprowadzały przede wszystkim dwa dekrety: dekret z dnia 4 marca 1953 r. o wzmożeniu walki z produkcją złej jakości (Dz.U. Nr 16, poz. 63 ze zm.) oraz dekret z dnia 4 marca 1953 r. o ochronie interesów nabywców w obrocie handlowym (Dz.U. Nr 16, poz. 64).

${ }^{39} \mathrm{~W}$ świetle kodeksu zobowiązań wada fizyczna występowała wówczas, gdy rzecz nie posiadała właściwości, o których istnieniu sprzedawca zapewnił kupującego, albo gdy rzecz miała wady zmniejszające jej wartość lub użyteczność ze względu na cel w umowie oznaczony albo wynikający z natury lub przeznaczenia rzeczy (art. 306 $\S 2$ k.z.). 
niej jakości ${ }^{40}$. W ustroju socjalistycznym natomiast pierwszoplanowym wyznacznikiem poziomu jakości rzeczy miała być nie wola stron umowy sprzedaży, lecz interes społeczeństwa ${ }^{41}$. Zasadnicze cechy jakościowe, jakim odpowiadać powinien produkt, określone zostały w aktach planowania i aktach ustalających normy produkcji (normy państwowe, resortowe, zakładowe) $)^{42}$. Umowy jedynie bliżej i dokładniej ustalały przeznaczenie produktu i jego cechy.

Pomimo opisanych powyżej zmian, przepisy kodeksu zobowiązań o rękojmi za wady fizyczne nie zostały w żaden sposób znowelizowane. W latach 1944-1964 obowiązywały więc w dalszym ciągu uregulowania międzywojenne. Zostały one jednak niejako ,zepchnięte na dalszy plan" przez niezwykle rozbudowane przepisy regulujące stosunki pomiędzy jednostkami gospodarki uspołecznionej. Obrót uspołeczniony unormowany został gąszczem przepisów, niekiedy sprzecznych ze sobą, tworzących nieskoordynowany zbiór wywołujący zasadnicze wattpliwości w procesie wykładni ${ }^{43}$. Pomimo, iż walka o należytą jakość towarów stała się jednym z głównych haseł głoszonych przez władze komunistyczne, rozbudowany system aktów szczególnych nie spełnił pokładanych w nim nadziei. O wadliwości funkcjonowania tego systemu świadczy m.in. znaczna liczba orzeczeń arbitrażowych dotyczących rękojmi. W zbiorze orzecznictwa arbitrażowego za lata 1949-1958 znajdujemy aż 45 orzeczeń dotyczących

${ }^{40}$ Zgodnie z art. 209 k.z. jeśli przedmiotem zobowiązania była rzecz oznaczona tylko co do gatunku, bez ściślejszego określenia, dłużnik powinien dać rzecz średniej jakości i dobroci.

${ }^{41}$ J. MAYZeL, Z zagadnień prawnej ochrony jakości produkcji, «PUG» 6.10/1953, s. 359 .

42 Tamże, s. 359.

43 Por. M. ANDREŁowicz, Jeszcze w sprawie nowych przepisów o dostawach, «PUG» 10.6/1957, s. 210; M. RYBICKI, Znaczenie kodyfikacji prawa cywilnego w okresie budowania socjalizmu (Z przemówienia Ministra Sprawiedliwości na posiedzeniu Sejmu PRL w dn. 21.V.1963 r.), «NP» 19.6/1963, s. 609-610; W. JAŚLAN, Warunki dostaw towarów ze skupu, «PUG»16.12/1963, s. 342- 343; J. SzYMAŃcZYK, Co obowiazuje? Jakie przepisy stosować z zakresu warunków dostaw, «Gospodarka Materiałowa» 13/1960, s. 464- 466. 
rękojmi ${ }^{44}$. Oczywiście nie są to wszystkie orzeczenia w tym przedmiocie, liczba ta odzwierciedla jednak ogólną tendencję do rozwiązywania sporów na drodze arbitrażu ${ }^{45}$.

W odróżnieniu od obrotu uspołecznionego, problematyce rękojmi w obrocie powszechnym poświęcono jedynie nieliczne, pozakodeksowe normy wprowadzane w drodze zarządzeń, instrukcji i okólników Ministra Handlu Wewnętrznego ${ }^{46}$. Niestety, akty te niejednokrotnie regulowały odpowiedzialność sprzedawców w sposób sprzeczny z przepisami k.z., naruszając podstawowe uprawnienia konsumentów ${ }^{47}$. Chociaż przepisy aktu prawnego niższego rzędu, jak trafnie podkreślano w literaturze ${ }^{48}$, nie mogły uchylać przepisów aktu wyższej rangi, to jednak w praktyce je uchylały. Wynikało to bowiem z faktycznego zastosowania przez sprzedawców instrukcji i okólników MHW w stosunku do klientów, chcących skorzystać z uprawnień z tytułu rękojmi.

Jak wcześniej wspomniano, pomimo zasadniczej transformacji ustrojowej i gospodarczej, przepisy kodeksu zobowiązań w zakresie rękojmi nie uległy zmianie. Również orzecznictwo Sądu Najwyższego, wbrew postulatom stawianym przez władze, nie wlało $\mathrm{w}$ te przepisy

44 Orzecznictwo Arbitrażowe za lata 1949-1958, Warszawa 1960.

${ }^{45} \mathrm{Z}$ drugiej strony to właśnie dorobek orzecznictwa arbitrażowego wpływał również na specyfikę instytucji rękojmi w stosunkach między j.g.u. Główna Komisja Arbitrażowa oraz komisje okręgowe wypracowały w tym zakresie szereg swoistych zasad, starały się bowiem łagodzić rygoryzm wynikający z przepisów o.w.d., niekiedy nawet poprzez wykładnię contra legem.

46 Por. np. zarządzenie Ministra Handlu Wewnętrznego z dnia 21 października $1952 \mathrm{r}$. w sprawie zasad i trybu postępowania placówek handlu detalicznego z reklamacjami jakościowymi, dotyczącymi artykułów przemysłowych (Dz.Urz. MHW Nr 9, poz. 56).

${ }^{47}$ Zgodnie z opisywanym w powyższym przypisie zarządzeniem, reklamacje mogły być zgłaszane przez nabywcę rzeczy w ciagu 4 dni od daty wykrycia wady, nie później jednak niż w ciągu 6 tygodni od daty wydania towaru. Zarządzenie to w sposób bardzo niekorzystny dla konsumenta skracało więc terminy do dokonania aktów staranności - z jednego miesiąca na 4 dni i z jednego roku do 6 tygodni. Ponadto zarządzenie przewidywało, iż nabywca wadliwej rzeczy mógł żądać jedynie wymiany towaru na dobry lub zwrotu ceny. Nie mógł natomiast domagać się stosownego obniżenia ceny.

48 J. GóRSKI, Niektóre zagadnienia odpowiedzialności sprzedawcy z tytułu rękojmi za wady towaru, «Zeszyty Naukowe WSE w Poznaniu» 3/1957, s. 97. 
nowej treści. Orzecznictwo sądowe z pierwszego dwudziestolecia PRL w zakresie rękojmi było nieliczne, zwłaszcza w porównaniu z bogatym dorobkiem arbitrażu w sprawach tego rodzaju. W praktyce bowiem, występowanie na drogę sądową przez podmioty prywatne w sprawach o rękojmię było bardzo rzadkie w tym okresie. Przyczyną takiego stanu rzeczy były nieustanne braki towarów na rynku. Konsument wolał zachować wadliwą rzecz niż realizować uprawnienia z tytułu rękojmi, zwłaszcza odstąpienie od umowy.

W 1947 r. rozpoczęto prace nad przygotowaniem projektu kodeksu cywilnego. W ciagu niespełna dwóch lat przygotowano pierwszy projekt, stanowiący kontynuację dorobku międzywojennej Komisji Kodyfikacyjnej ${ }^{49}$. Po przełomie jaki nastapił w 1948 r. na sierpniowowrześniowym plenum KC PPR, przerwano jednak prace nad gotowym projektem i całkowicie zmieniono koncepcję prac kodyfikacyjnych ${ }^{50}$.

49 Projekt obejmował 5 ksiagg, które z wyjątkiem ostatniej (prawo spadkowe), zostały opublikowane w Demokratycznym Przeglądzie Prawniczym (DPP) i w osobnych odbitkach jako druk urzędowy (zob. DPP 1947, nr 12; DPP 1948, nr 4, 6, 8, 9, 10, 11 i 12; DPP 1949 nr 1,2,3). Numerację poszczególnych projektów k.c. podaję za W. Czachórskim, Przebieg prac nad kodyfikacja prawa cywilnego PRL, «Studia Prawnicze» 26-27/1979, s. 8.

${ }^{50}$ S. GrodzISKI, Prace nad kodyfikacja i unifikacja polskiego prawa prywatnego (1919-1947), «KPP»1.1-4/1992, s. 28; TENŻE, Z dziejów unifikacji polskiego prawa cywilnego, «CPH» 37.2/1985, s. 299. Jak wskazał J. WAsILKowsKi, Kodyfikacja prawa cywilnego w Polsce, «NP» 5.12/1950, s. 4 ,wobec postępującej w gwałtownym tempie rewolucyjnej przebudowy społecznej w kierunku socjalizmu - okazało się wkrótce, że cel prac kodyfikacyjnych został określony niewłaściwie i że wskutek tego kodeks opracowany według planu z 1947 r. byłby anachronizmem już w chwili ogłoszenia. Stało się oczywistym, że prawo cywilne polskie - jeśli ma być czynnikiem prawdziwego postępu, czynnikiem ułatwiającym i przyspieszającym budowę ustroju socjalistycznego - wymaga przede wszystkim zasadniczej rewizji swych założeń ideologicznych". Ta wypowiedź głównego redaktora projektu stanowiła samokrytykę (zob. Tamże, s. 4, przyp. 2). Przyczyny dokonanej w 1949 r. zmiany kierunku prac kodyfikacyjnych analizował z perspektywy ponad 40 lat J. SKĄPSKI, Kodeks cywilny z 1964 r. Blaski i cienie kodyfikacji oraz jej perspektywy, «KPP»1.1-4/1992, s. 5761). Zob. także: Z. Radwański, Prawo cywilne PRL, «CPH» 47.1-2/1995, s. 24; A. LitYŃsKi, Na drodze do kodyfikacji prawa cywilnego w Polsce Ludowej, [w:] Prawo wczoraj i dziś. Studia dedykowane profesor Katarzynie Sójce-Zielińskiej, Warszawa 2000, s. 140-141. 
Stwierdzono, iż prawo cywilne oparte na przepisach międzywojennych wymaga głębokiej przebudowy oraz konieczne jest dostosowanie przepisów o zobowiązaniach do potrzeb obrotu socjalistycznego.

W tych warunkach pomimo, iż sprawę opracowania nowych kodeksów Polski Ludowej uznano za sprawę pilną i konieczną ${ }^{51}$, na kodeks cywilny przyszło poczekać aż do 23 kwietnia $1964 \mathrm{r}^{52}$ Wejście w życie tego kodeksu z dniem 1 stycznia 1965 r., rozpoczeło nowy etap w rozwoju instytucji rękojmi w polskim prawie. Nowy kodeks w zakresie odpowiedzialności sprzedawcy powielał znaczną część dotychczasowych rozwiązań prawnych. Wprowadził też pewne modyfikacje w stosunku do poprzedniej regulacji. Modyfikacje te dotyczyły przede wszystkim uprawnień kupującego z tytułu rękojmi, zarówno katalogu tych praw, jak i sposobu ich wykonywania. Oprócz trzech uprawnień nabywcy wymienionych w kodeksie z 1933 r., kodeks cywilny przyznawał kupującemu nowe uprawnienie - żądanie naprawy ${ }^{53}$. Było ono jednak ograniczone do tych wypadków gdy przedmiotem sprzedaży była rzecz oznaczona co do tożsamości, a sprzedawcą był wytwórca tej rzeczy. Ponadto sprzedawca mógł odmówić usunięcia wady, gdyby wymagało ono nadmiernych kosztów. Był to kolejny etap w ewolucji instytucji rękojmi: obok tzw. środków edylskich, przyznano nabywcy dwa uprawnienia, zwane niekiedy uprawnieniami z rękojmi niewłaściwej. Pod pewnymi względami kodeks cywilny stanowił więc „krok naprzód" w historycznym rozwoju instytucji rękojmi. Część jednak zmian stanowiła regres $\mathrm{w}$ uregulowaniu tej instytucji. Poza rozszerzeniem liczby uprawnień nabywcy, kodeks cywilny wprowadził bowiem zasadnicze ograniczenia w zakresie możliwości korzystania z tych praw. Najważniejsze ograniczenie dotyczyło możliwości odstąpienia od umowy. Kupujący nie mógł skorzystać z tego uprawnienia, jeśli sprzedawca oświadczył gotowość natychmiastowej wymiany rze-

${ }^{51}$ Por. Uchwała Prezydium Rzadu, «NP» 5.10/1950, s. 2.

${ }_{52}$ Ustawa z dnia 23 kwietnia 1964 r. - Kodeks cywilny (Dz.U. Nr 16, poz. 93 z późn. $z m$.).

${ }^{53}$ Art. $561 \S 2$ k.c. 
czy wadliwej na rzecz wolną od wad albo niezwłocznie wady usuną ${ }^{54}$. Najistotniejsze uprawnienie nabywcy mogło więc zostać zniweczone poprzez realizację jednego z kontruprawnień sprzedawcy.

Podobnie jak kodeks zobowiązań, kodeks cywilny ograniczał ściśle określonymi terminami wykonanie uprawnień z tytułu rękojmi. Zasadniczy termin wynosił rok i był identyczny jak w kodeksie zobowiązań (art. 568 k.c.). W porównaniu z poprzednią regulacją skrócono natomiast termin dotyczący rękojmi za wady fizyczne budynku $\mathrm{z}$ pięciu do trzech lat ${ }^{55}$. Zmiana nastapiła także w zakresie terminologii. Kodeks zobowiązań stwierdzał, iż po upływie wskazanych terminów nie można było dochodzić sądownie roszczeń z tytułu rękojmi, kodeks cywilny wprowadził bardziej poprawną formułę, iż uprawnienia $\mathrm{z}$ tytułu rękojmi wygasały.

Na poziom ochrony praw konsumenta w latach 1965-1996 wpłynęło przede wszystkim wprowadzenie do kodeksu cywilnego gwarancji. Uregulowano więc nową instytucję prawną, która w założeniu miała służyć ochronie praw konsumenta. Zawarty w przepisach ją regulujących art. 579 k.c. przewidywał, iż nabywca, który otrzymał gwarancję, mógł wykonywać uprawnienia z tytułu rękojmi za wady fizyczne rzeczy dopiero wówczas, gdy sprzedawca we właściwym czasie nie uczynił zadość obowiązkom wynikającym z gwarancji. Wprowadzono więc swoistą sekwencyjność korzystania z uprawnień z tytułu gwarancji i rękojmi. Istniejący zbieg roszczeń pomiędzy oboma reżimami odpowiedzialności ustawodawca rozstrzygnął na korzyść gwarancji, wprowadzając jej bezwzględne pierwszeństwo. Nowa instytucja w praktyce więc chroniła bardziej sprzedawców niż konsumentów, stanowiła privilegium odiosum ${ }^{56}$. Dyspozytywny charakter unormowania gwaran-

${ }^{54}$ Art. $560 \S 1$ k.c.

${ }_{55}$ Zob. na temat motywów tej zmiany: S. BuczKowski, Wplyw postępu technicznego w przemyśle na postać i treść unormowań prawnych, «Studia Prawnicze» 22/1969, s. 13.

56 M. Nesterowicz, Gwarancja przy sprzedaży w kodeksie cywilnym. Ocena $i$ wnioski, «Studia Prawnicze» 43.2/1990, s. 251; Tenże, Ochrona prawna nabywcy pojazdu mechanicznego z wadami, Warszawa 1988, s. 83; A. Ohanowicz, J. Górski, Zarys prawa zobowiazań, Warszawa 1970, s. 285; S. SoŁTYsińsKi, Ochrona praw 
cji i zniweczenie na długi okres (najczęściej jednego roku) uprawnień z tytułu rękojmi spowodowały oddanie niejako, na czas trwania gwarancji, kupującego „we władzę" gwaranta ${ }^{57}$. Rozwiązanie wprowadzone przez kodeks cywilny stanowiło „krok wstecz” w porównaniu ze stanem obowiązującym przed 1 stycznia 1965 r., zdecydowanie obniżając poziom ochrony konsumenta ${ }^{58}$. Pomimo zdecydowanej krytyki przedstawicieli doktryny, postulujących ,oderwanie” rękojmi od gwarancji ${ }^{59}$, rozwiązanie to przetrwało ponad 30 lat.

Kolejne zmiany w zakresie uprawnień nabywcy w obrocie powszechnym nastapiły w latach osiemdziesiątych XX w. Już od schyłku lat siedemdziesiątych coraz częściej dochodziły do głosu postulaty zapewnienia większej ochrony słabszej stronie umowy sprzedaży konsumentowi ${ }^{60}$. W okresie gospodarki centralnie sterowanej, wy-

konsumenta, «PiP»26.12/1971, s. 894-895; J. KufEL, W. SiUdA, Cywilnoprawne instrumenty ochrony indywidualnego nabywcy, «NP» 34.5/1978, s. 714; J. SKĄPSKI, Rękojmia za wady, [w:] System prawa cywilnego. Prawo zobowiazań-część szczegółowa, red. S. GrzYBowski, III.2, Wrocław-Warszawa-Kraków-Gdańsk 1976, s. 152; K. PiAsecki, Problematyka jednolitości i rozbieżności praktyki sqdowej w stosowaniu przepisów o gwarancji i rękojmi. Próba oceny, «Studia Prawnicze» 2/1990, s. 231-233; W. URuszczaK, Konsument wymaga ochrony, «Rzeczpospolita» $\mathrm{z}$ dnia 28 lipca $1992 \mathrm{r}$.

57 W. Czachórski, Prawo zobowiazań w zarysie, Warszawa 1968, s. 451; TenżE, Zobowiazania. Zarys wyktadu, Warszawa 1983, s. 332-333; M. Nesterowicz, Gwarancja..., s. 251.

58 T. SMARZYŃSKI, Funkcjonowanie instytucji rękojmi za wady fizyczne i gwarancji w świetle badań empirycznych, «RPEiS» 33.2/1973, s. 167; M. SoŚNIAK, Czy instytucja rękojmi za wady fizyczne $w$ k.c. zapewnia $w$ dostatecznej mierze ochrone nabywcy towarów złej jakości?, [w:] Zagadnienia prawne obrotu towarowego, Katowice 1977, s. 93.

59 M. Nesterowicz, Gwarancja..., s. 255.

${ }^{60}$ Zob. np. S. WŁodyKa, Ochrona interesów konsumenta przez rękojmię za wady fizyczne towarów, «PiP»33.10/1978, s. 18-32. Problematyce tej poświęcono m.in. konferencję naukową w dniach 23-25 kwietnia 1977 r. na temat prawnych aspektów ochrony konsumenta (zob. C. StarośCIAK, Konferencja naukowa w IPiP PAN, «PiP» 32.11/1977, s. 156-158; referaty zostały opublikowane w Studiach Prawniczych 1/1978, s. 5-114) oraz konferencję w przedmiocie problemów funkcjonowania sytemu ochrony interesów konsumentów w Polsce zorganizowaną w dniach 20-22 listopada 
stępujące rozległe i głębokie deficyty towarowe odbierały nabywcy możliwość swobodnego wyboru towaru i praktycznego skorzystania ze swoich uprawnień ${ }^{61}$. Odstapienie od umowy, które w systemie gospodarki kapitalistycznej stanowiło główny oręż nabywcy w walce o należytą jakość produktów, w warunkach rynku sprzedawcy stało się środkiem ostatecznym.

Podobnie jak w latach wcześniejszych, problematykę sprzedaży detalicznej i rozpatrywania reklamacji konsumenckich unormowano w drodze zarządzeń i instrukcji Ministra Handlu Wewnętrznego ${ }^{62}$. Akty te jednakże często faworyzowały sprzedawców, którymi najczęściej były jednostki gospodarki uspołecznionej. Ich treść była niejednokrotnie sprzeczna z przepisami kodeksu cywilnego i pozostawała w jaskrawej sprzeczności z deklarowaną przez państwo ogólną linią polityki

1977 r. (sprawozdanie autorstwa B. Kordasiewicza zamieszczono w «PiP» 10.2/1978, s. 163-164). Kontynuacją dyskusji podjętej na ostatniej ze wskazanych konferencji było zebranie w dniu 10 marca 1978 r. (zorganizowane przez IPiP PAN oraz Zakład Prawa Administracyjnego Uniwersytetu Łódzkiego), poświęcone proceduralnym aspektom ochrony konsumenta, w tym problemów wyłaniających się na tle postępowania reklamacyjnego (zob. wiecej: B. Kordasiewicz, Proceduralne aspekty ochrony konsumenta, «PUG»31.4/1978, s. 119-121 oraz TENŻE, Proceduralne aspekty ochrony konsumenta (konferencja w Warszawie), «PUG» 31.10/1978, s. 174-175). Zagadnień ochrony konsumenta dotyczyła również konferencja naukowa Instytutu Badania Prawa Sądowego, zob.: K. KRzeкотоwska, E. Warzocha, Funkcjonowanie gwarancji i rękojmi za wady fizyczne sprzedanej rzeczy, «Zeszyty Naukowe IBPS» 12/1979, s. 199-206.

${ }^{61}$ C. ŻuŁawska, Nowe przepisy o sprzedaży detalicznej $i$ gwarancji, «PiP» 39.1/1984, s. 19.

${ }^{62}$ Instrukcja nr 2 MHW z dnia 29 czerwca 1968 r. w sprawie załatwiania w sklepach jakościowych reklamacji nabywców oraz zamiany artykułów przemysłowych (Dz. Urz. MHW nr 26, poz. 53); instrukcja nr 1 MHW z dnia 20 stycznia 1971 r. w sprawie załatwiania w sklepach jakościowych reklamacji artykułów spożywczych zgłaszanych przez kupujących (Dz.Urz. MHW nr 1, poz. 2); zarządzenie nr 4 MHWiU z dnia 12 lutego 1980 r. w sprawie załatwiania w uspołecznionym handlu detalicznym reklamacji wadliwych towarów nieżywnościowych i wniosków o zamianę towarów nie mających wad (Dz.Urz. MHWiU nr 2, poz. 2). 
prokonsumenckiej ${ }^{63}$. Instrukcje ministerialne bowiem de facto kształtowały sytuację nabywcy, chociaż formalnie go nie obowiązywały ${ }^{64}$.

Wyżej opisane niedoskonałości i wady regulacji prawnych starało się łagodzić orzecznictwo. Odegrało ono wielką rolę we wzmocnieniu systemu ochrony kupującego poprzez twórczą wykładnię przepisów kodeksu cywilnego. Na takie stanowisko SN duży wpływ miała doktryna prawna wskazująca na tendencję światową i kierunki zmian w dążeniu do ochrony słabszej strony stosunku prawnego. Stroną tą, zwłaszcza w ustroju socjalistycznym - przy dominacji sprzedawcy i producenta, był nabywca.

Dopiero w 1983 r. wydano pierwszy powszechnie obowiązujący akt w zakresie sprzedaży z udziałem konsumentów - uchwałę nr 71 Rady Ministrów w sprawie ogólnych warunków sprzedaży detalicznej towarów oraz ogólnych warunków gwarancyjnych dotyczących towarów trwałego użytku, sprzedawanych przez jednostki handlu uspołecznionego ${ }^{65}$. Przełomowe znaczenie tego aktu polegało przede wszystkim na tym, iż wprowadzał on rozwiązania korzystne dla konsumentów, niekiedy idące nawet dalej niż litera kodeksu cywilnego, zgodne jednakże z jego duchem ${ }^{66}$. Uchwała $\mathrm{nr} 71$ nie tyle bowiem twórczo rozwijała przepisy k.c. o rękojmi, ile odwoływała się do usta-

${ }^{63}$ Takie ukształtowanie ich treści było przyczyną krytycznych wypowiedzi w piśmiennictwie. Na uwagę zasługuje w tym zakresie artykuł T. SMARZYŃsKIEGO, Funkcjonowanie instytucji rękojmi..., s. 153-168, który stosowanie m.in. przepisów instrukcji nr 2 MHW uczynił przedmiotem badań empirycznych polegających na przeprowadzeniu ustnych wywiadów z personelem sklepów i przedstawicielami zarządów przedsiębiorstw handlowych oraz wywiadów pisemnych, którym autor nadał formę korespondencji klienta ze sprzedawcą. Wyniki badań autor szczegółowo opisał oraz zobrazował tabelami. Zarządzenia i instrukcje MHW stały się nawet przedmiotem interpelacji poselskiej, zwracającej uwagę na sprzeczność tych przepisów z kodeksem cywilnym (C. ŻuŁaWsKa, Nowe przepisy..., s. 22).

${ }^{64}$ C. ŻuŁawsKa, Nowe przepisy..., s. 20; TeJże, Uwagi o sytuacji prawnej konsumenta, «PiP» 35.10/1980, s. 43.

${ }^{65}$ Uchwała z dnia 13 czerwca 1983 r. (M.P. Nr 21, poz. 118). Wydanie ogólnych warunków umów odnoszących się do obrotu z udziałem konsumentów postulowała wcześniej E. ŁĘTOWSKA, Ochrona konsumenta z punktu widzenia polityki prawa, 33.4/1978, s. 27).

${ }^{66}$ C. ŻuŁawska, Nowe przepisy..., s. 22. 
lonego w orzecznictwie Sądu Najwyższego oraz w piśmiennictwie naukowym kierunku wykładni tych przepisów ${ }^{67}$. Jak wcześniej wspomniano, przyjmowana $\mathrm{w}$ doktrynie i judykaturze interpretacja natomiast niemal zawsze odbiegała na korzyść konsumentów w stosunku do realnego poziomu przyznanej im ochrony ${ }^{68}$. Utrwalenie tej prokonsumenckiej wykładni w akcie normatywnym wpłynęło na polepszenie sytuacji prawnej nabywcy ${ }^{69}$. Ponadto uchwała $\mathrm{nr} 71$ zawierała wiele przepisów stanowiących bądź powtórzenie artykułów kodeksu cywilnego, bądź zawierających zasady oczywiste dla doktryny i judykatury, jednakże nie zawsze jasne dla praktyki handlu i konsumenta ${ }^{70}$. Zaznaczyć jednakże w tym miejscu trzeba, iż równocześnie $\mathrm{z}$ jakościową zmianą przepisów nie nastapiły zmiany w sferze gospodarki. Trafnie ujął to S. Włodyka wskazując, iż nawet najlepiej skonstruowane przepisy zawodza, w sytuacji gdy struktura rynku nie pozwala na ich realizację. Pozostają wówczas tylko martwą literą prawa ${ }^{71}$.

Kolejne akty w tej dziedzinie - zarówno rozporządzenie Rady Ministrów z 30 maja 1995 r. ${ }^{72}$, jak i z 25 czerwca 2002 r. ${ }^{73}$ - chociaż zo-

${ }^{67}$ E. ŁętowsKa, Nowe „konsumenckie” warunki umów, «PUG» 23.10/1983, s. 287.

${ }^{68}$ Por. orzecznictwo i poglądy doktryny przytoczone w artykule J. KufLA i W. Siudy, Cywilnoprawne instrumenty..., s. 711-721. Zob. także: E. ŁĘTOwSKA, Gwarancja i rękojmia. Główne tendencje orzecznictwa Sadu Najwyższego, «NP» 44.4/1987, s. 43-44.

${ }^{69}$ E. ŁętowsKa, Nowe „konsumenckie”..., s. 287.

${ }^{70}$ Tytułem przykładu można wskazać $\S 13$ ust. 1 stanowiący, iż nie podlegały reklamacji wady towaru, o których kupujący wiedział w chwili wydania mu towaru. Wprowadzono również w tym ustępie domniemanie, iż kupujący wiedział o widocznych wadach nabytego towaru jeżeli na dowodzie sprzedaży i wywieszce towarowej lub opakowaniu była zamieszczona informacja, że towar ten był sprzedawany po obniżonej cenie, z powodu wad, jako niepełnowartościowy. Kolejnym przykładem był $\S 23$ ust. 1 zawierający wskazanie, iż niezależnie od uprawnień z tytułu rękojmi nabywcy przysługiwały roszczenia odszkodowawcze na zasadach ogólnych.

71 S. WŁodyKa, Cywilnoprawna ochrona jednostki jako nabywcy wadliwego produktu, «Zeszyty Naukowe UJ - Prace Prawnicze» 85/1979, s. 123.

72 Rozporządzenie Rady Ministrów z dnia 30 maja 1995 r. w sprawie szczegółowych warunków zawierania i wykonywania umów sprzedaży rzeczy ruchomych z udziałem konsumentów (Dz.U. Nr 64, poz. 328).

${ }^{73}$ Rozporządzenie Rady Ministrów z dnia 25 czerwca 2002 r. w sprawie szczegółowych warunków zawierania i wykonywania umów sprzedaży między przedsiębiorcami a konsumentami (Dz.U. Nr 96, poz. 851). 
stały wydane już w zupełnie innym ustroju społeczno-gospodarczym, w zakresie odpowiedzialności sprzedawcy za nienależytą jakość towa$\mathrm{ru}$, powielały w znacznym stopniu rozwiązania uchwały $\mathrm{nr} 71$.

Jak wcześniej wspomniano, do przepisów o sprzedaży z udziałem konsumentów wprowadzono w tym czasie szereg przepisów opartych na dorobku orzecznictwa. Przykładem takiej regulacji było wskazanie, iż do wymiany za towar wadliwy mógł być użyty przez sprzedawcę wyłącznie towar wolny od wad - fabrycznie nowy ${ }^{74}$. Uwzględniono w tym zakresie liczne orzeczenia SN, które korygowały rozpowszechnioną praktykę polegającą na wydawaniu nabywcy w zamian za wadliwy towar rzeczy reperowanej, renowanej lub używanej (pochodzącej z tzw. zwrotów) ${ }^{75}$. Podobnie na dorobku judykatury oparto przepis, iż przy wymianie towaru wadliwego na wolny od wad lub w przypadku odstapienia przez kupującego od umowy z powodu wad w towarze nie można było stosować potrącenia $\mathrm{z}$ ceny za skutki normalnego zużycia towaru, stanowiącego przedmiot uznanej reklamacji (tzw.

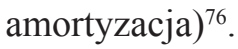

Następne zmiany w systemie ochrony nabywcy wadliwej rzeczy nastapiły w latach dziewięćdziesiątych XX w. Przełom ustrojowy i gospodarczy, jaki dokonał się w 1989 r., spowodował konieczność dokonania głębokich korekt całego systemu prawa, a w jego ramach także prawa cywilnego ${ }^{77}$. W zakresie instytucji rękojmi zmiany doko-

$74 \S 20$ ust. 1 uchwały $\mathrm{nr} 71 ; \S 21$ ust. 1 rozporządzenia z 1995 r.; $§ 20$ ust. 1 rozporządzenia z 2002 r. Dwa ostatnie akty trafnie precyzowały, iż powyższa reguła nie miała zastosowania, gdy przedmiotem sprzedaży była rzecz używana.

75 E. ŁętowsKa, C. ŻuŁawsKa, Komentarz do ogólnych warunków umów konsumenckich, Warszawa 1986, s. 77 oraz podane tam orzecznictwo (przyp. 65).

$76 \S 20$ ust. 2 uchwały nr 71; 21 ust. 2 rozporządzenia z 1995 r.; $§ 20$ ust. 2 rozporządzenia z 2002 r. Por. też orzecznictwo podane w: E. ŁęTOwsKA, C. ŻUŁAWsKA, Komentarz do ogólnych warunków..., s. 77 przyp. 66.

77 A. Brzozowski, Reforma prawa cywilnego w latach 1990-1996, [w:] Kodeks cywilny. Kodeks postępowania cywilnego, Warszawa 1997, s. 11-12. Prace nad zmianą kodeksu cywilnego rozpoczęto już w 1986 r. (zob. więcej: Powołanie Komisji ds. reformy prawa cywilnego, «PiP» 41.12/1986, s. 111; R. TupIN, Reforma prawa cywilnego, «PUG» 38.1/1987, s. 1-3). Społeczne inicjatywy miały natomiast miejsce już od początku lat osiemdziesiątych ubiegłego wieku (zob. S. GrZYBowsKI, 
nane zostały ustawą z 28 lipca 1990 r. ${ }^{78}$ (nowela lipcowa) oraz ustawą z 23 sierpnia 1996 r. (nowela sierpniowa) ${ }^{79}$.

Nowela lipcowa wprowadziła nieliczne zmiany w instytucji rękojmi polegające głównie na dostosowaniu jej do potrzeb gospodarki rynkowej. Najistotniejsza zmiana wprowadzona przez ustawę z 28 lipca 1990 r. w przepisach o rękojmi, polegała na wprowadzeniu zakazu ograniczania lub wyłączania odpowiedzialności za wady w umowach z udziałem konsumentów, za wyjątkiem wypadków określonych w przepisach szczególnych (art. 558 § 1 k.c. zdanie drugie w nowym brzmieniu). Zrealizowano w ten sposób wielokrotnie wcześniej zgłaszany postulat wzmocnienia pozycji prawnej konsumenta ${ }^{80}$.

Zagadnienia kodyfikacji polskiego prawa cywilnego (organizacja i wyniki pracy 19191992), «KPP» 1.1-4/1992, s. 108-114). Zobacz także L. GóRnicki, Kodyfikacja prawa prywatnego, [w:] System prawa prywatnego. Prawo cywilne - część ogólna, red. M. SAFJAn, I, Warszawa 2007, s. 124-126.

78 Ustawa o zmianie ustawy - Kodeks cywilny (Dz.U. Nr 55, poz. 321). Nowela lipcowa weszła w życie z dniem 1 października 1990 r.

79 Ustawa z dnia 23 sierpnia o zmianie ustawy - Kodeks cywilny (Dz.U. Nr 114, poz. 542). Nowelizacja ta weszła $w$ życie $z$ dniem 28 grudnia $1996 \mathrm{r}$. Na temat przebiegu prac nad tym etapem reformy prawa cywilnego zob. W. CzAchóRski, Perspektywy reformy prawa cywilnego, «PiP» 50.1/1995, s. 3-10; A. Mączyński, K. Zawada, Zamierzona nowelizacja kodeksu cywilnego, «KPP»4.3/1995, s. 417. W zakresie wyników tych prac zob.: W. JAŚLAn, Drugi etap reformy prawa cywilnego, [w:] Kodeks cywilny, Warszawa 1996, s. 6-9; A. SzPUnAR, Nowelizacje kodeksu cywilnego, [w:] Kodeks cywilny, Warszawa 2001, s. XXVI-XXVIII.

${ }^{80}$ Zob. Ocena stanu prawa cywilnego $i$ rolnego (przygotowana przez zespót prawa cywilnego $i$ rolnego Rady Legislacyjnej przy Prezesie Rady Ministrów), «NP» 41.10/1985, s. 3-39, (zob. w szczególności s. 21-25, dotyczące legislacyjnych problemów ochrony konsumenta); K. KRzекотоwsKA, Niektóre problemy prawa cywilnego w świetle dokumentu „Ocena stanu prawa cywilnego i rolnego”, «Problemy Praworządności» 4/1986, s. 32; Z. RADWAŃSKI, Kierunki reformy prawa cywilnego, 42.4/1987, s. 17; Główne kierunki prac nad reforma prawa cywilnego (wystapienie Ministra Sprawiedliwości dra Lecha Domeradzkiego na inauguracyjnym posiedzeniu Komisji do Spraw Reformy Prawa Cywilnego w dniu 20 listopada 1986 r.), «NP» 43.1/1987, s. 4-5; M. JАKUBEK, Wybrane problemy nowelizacji kodeksu cywilnego, «PiP» 43.2/1988, s. 111. 
Głębszych zmian w zakresie odpowiedzialności sprzedawcy dokonała nowela sierpniowa. Przede wszystkim całkowitej transformacji uległ art. 579 k.c., który w nowym brzmieniu stanowił, iż kupujący mógł wykonywać uprawnienia z tytułu rękojmi za wady fizyczne rzeczy, niezależnie od uprawnień wynikających $\mathrm{z}$ gwarancji. Uwzględniono więc $\mathrm{w}$ tym zakresie postulaty doktryny i w miejsce bezwzględnego priorytetu gwarancji wprowadzono równoległość obu reżimów, pozwalając nabywcy na dokonanie wyboru pomiędzy skorzystaniem z uprawnień tytułu rękojmi bądź gwarancji. Jednakże interpretacja wzajemnego związku pomiędzy rękojmią a gwarancja, na tle zwrotu o „niezależnym” wykonywaniu uprawnień, okazała się rozbieżna ${ }^{81}$. Ewa Łętowska wskazała, iż praktyka pozasądowa jednoznacznie opowiedziała się za wykładnią przekreślającą sens wprowadzonych zmian i za uczynieniem konsumenta „niewolnikiem gwarancji”"2. Dokonanie ,pierwszego wyboru” przez klienta optującego za gwarancją w ocenie wielu sprzedawców wykluczało na przyszłość (a więc na czas trwania gwarancji i - praktycznie - rękojmi, ponieważ ustawodawca zrezygnował z rękojmi pogwarancyjnej) możliwość skorzystania z rękojmi, niezależnie od tego, ile i jakie wady by wystapiły, i jak nierzetelne okazałyby się świadczenia gwaranta ${ }^{83}$. Powyższe podejście znacznie więc pogarszało sytuację konsumenta nawet $\mathrm{w}$ stosunku do praktyki sprzed noweli z $1996 \mathrm{r}^{84}$

${ }^{81}$ E. ŁęTOwSKA, Zbieg norm w prawie cywilnym, Warszawa 2002, s. 109; TEJżE, Prawo umów..., s. 436.

82 E. Łętowska, Zbieg norm..., s. 109-110; Tejże, Prawo umów..., s. 437 (zob. zwłaszcza przypis 1).

83 E. ŁętowsKa, Zbieg norm..., s. 110; Tejże, Prawo umów..., s. 437.

${ }^{84}$ Interpretację taką przyjął m.in. J. KRAuss, Zmiany kodeksu cywilnego $w$ odniesieniu do rękojmi i gwarancji, «PPH» $1997 \mathrm{nr}$ 1, s. 16) który wskazał, iż „kupujący wybierając uprawnienia płynące $\mathrm{z}$ rękojmi traci możliwość realizacji uprawnień wynikających z gwarancji. Przy wyborze uprawnień gwarancyjnych kupujący zresztą już po roku utraci uprawnienia z tytułu rękojmi. Paradoksalnie wobec tego, zmiany przepisów kodeksu cywilnego w tym zakresie w pewnym sensie mogą prowadzić do pogorszenia sytuacji kupującego". 
Wyżej wspomniana nowelizacja kodeksu cywilnego ograniczyła ponadto w pewnym stopniu możliwość tamowania przez sprzedawcę uprawnienia nabywcy do odstapienia od umowy. Sprzedawca w świetle nowej regulacji musiał niezwłocznie wymienić rzecz wadliwą na wolną od wad, nie mógł natomiast bronić się „oświadczeniem gotowości natychmiastowej wymiany”. Kontruprawnienie sprzedawcy do udaremnienia odstapienia od umowy mogło być przez niego wykorzystane zasadniczo tylko jeden raz, chyba że wady miały charakter nieistotny. Dokonane zmiany pomimo, iż w założeniu miały zwiększać ochronę przysługującą nabywcy, w istocie wprowadzały kolejne ograniczenie w realizacji przysługujących mu praw. W 1996 r. po raz pierwszy bowiem uzależniono wykonywanie uprawnień płynących z rękojmi przy sprzedaży od stopnia istotności wady. Samo zaś pojęcie miało charakter nieostry i niedookreślony. Trafnie C. Żuławska stwierdziła, iż tak znowelizowany art. $560 \S 1$ k.c. zawierał unormowanie anachroniczne, a jednocześnie krzywdzące dla konsumenta ${ }^{85}$. Ponadto rozwiązanie to dawało sprzedawcy swoisty „udział" w prawie wyboru uprawnień z tytułu rękojmi, w efekcie czego naruszono konstrukcję tej instytucji prawnej. Od czasów rzymskich bowiem „,poprzez wielkie kodyfikacje XIX w. możność swobodnego rozwiązania kontraktu kupna (actio redhibitoria) była i jest prawem nabywcy" $"$.

Kolejny, ostatni z omawianych etapów w rozwoju odpowiedzialności sprzedawcy za wady, dokonany został w Polsce ustawą z dnia 27 lipca 2002 r. o szczególnych warunkach sprzedaży konsumenckiej oraz o zmianie Kodeksu cywilnego, która weszła w życie w dniu 1 stycznia $2003 r^{87}$. Geneza wprowadzenia tej nowej regulacji była

${ }^{85}$ C. ŻUŁawsKa, Uwagi o propozycjach zmian przepisów o rękojmi za wady, «KPP» 7.3/1996, s. 596.

86 Tamże, s. 596.

${ }^{87}$ Dz.U. Nr 141, poz. 1176 ze. zm. Zob. również J. SzczotKA, Sprzedaż konsumencka. Komentarz, Lublin 2004; M. Pecyna, Ustawa o sprzedaży konsumenckiej. Komentarz, Kraków 2004; E. WIECZOREK, Sprzedaż konsumencka, [w:] Europejskie prawo konsumenckie a prawo polskie, red.: E. NowińsKa i P. CyBulA, Kraków 2005, s. 161-206; M. CZEPELAK, Zagadnienia kolizyjnoprawne ochrony konsumenta, [w:] Europejskie prawo konsumenckie a prawo polskie..., s. 517-518; M. GAJEK, Niezgodność 
związana z dążeniami Polski do przystąpienia do Unii Europejskiej. Warunkiem członkostwa było dostosowanie prawa państwa kandydującego do acquis communautaire - prawnego dorobku Unii Europejskiej. Prawo unijne natomiast regulowało zagadnienie odpowiedzialności sprzedawcy za nienależyta jakość świadczenia w obrocie konsumenckim w sposób zasadniczo odmienny od prawa polskiego.

W prawie Unii Europejskiej na przełomie XX i XXI wieku, pod wpływem idei harmonizacji prawa, dokonano rewolucyjnej zmiany w klasycznych zasadach odpowiedzialności ${ }^{88}$. Tradycyjną rękojmię zastapiono pojęciem niezgodności z umową. W większości krajów członkowskich dotychczasowa regulacja odpowiedzialności za wady opierała się na zasadach recypowanych z prawa rzymskiego. Zasady te jednak przez kilkanaście wieków ewoluowały w bardzo zróżnicowany sposób w poszczególnych państwach. Dlatego też wprowadzenie jednolitych zasad obrotu towarami i związanej z tym odpowiedzialności sprzedawcy za nienależytą jakość świadczenia stało się konieczne dla urzeczywistnienie idei rynku wewnętrznego i swobodnego przepływu towarów.

Podstawowym aktem wspólnotowym w zakresie odpowiedzialności sprzedawcy była dyrektywa 1999/44/EC Parlamentu Europejskiego oraz Rady z dnia 25 maja 1999 r. w sprawie niektórych aspektów

z umowa jako przesłanka odpowiedzialności sprzedawcy towaru konsumpcyjnego, «MoP»11.5/2003, s. 207-210; J. Pisuliński, Sprzedaż konsumencka, [w:] System prawa prywatnego. Prawo zobowiazań - część szczegółowa, VII, Warszawa 2004, s. 156-214; T. KIERZYK, Odpowiedzialność za niezgodność produktu z umowa, «Rejent»14.7/2004, s. 91-106; M. OLCZYK, Sprzedaż konsumencka, Warszawa 2006; R. Stefanicki, Uprawnienia konsumenta z tytułu braku zgodności towaru z umowa w świetle ustawy o szczególnych warunkach sprzedaży, «Studia Prawa Prywatnego» 3-4/2007, s. 49-80; E. Habryn-Motawska, Niezgodność towaru konsumpcyjnego z umowq sprzedaży konsumenckiej, Warszawa 2010.

${ }^{88}$ Dyrektywa 1999/44/WE wprowadziła tak istotne zmiany w zakresie dotychczasowych pojęć prawnych, iż uznano ją za przejaw „zrywania” z dotychczasową tradycją głównych europejskich systemów prawa, a nawet stwierdzono, iż wywołała cywilistyczne trzęsienie ziemi (cytuję za C. ŻUŁAWsKA, Uwagi o ,europeizacji” prawa umów, «KPP 10.2/2001, s. 234). 
sprzedaży towarów konsumpcyjnych i związanych z tym gwarancji ${ }^{89}$. Dostosowanie prawa polskiego do prawa Unii Europejskiej wymagało natomiast implementacji tej dyrektywy. Implementacja ta została dokonana ww. ustawą z dnia 27 lipca 2002. Od momentu wejścia jej w życie odpowiedzialność sprzedawcy za nienależyta jakość świadczenia zaczęła podlegać jednemu z dwóch reżimów prawnych: przewidzianej w kodeksie cywilnym tradycyjnej instytucji rękojmi bądź wprowadzonemu nową ustawą reżimowi sprzedaży konsumenckiej ${ }^{90}$. Drugi ze wskazanych systemów odpowiedzialności znalazł zastosowanie do dokonywanej w zakresie działalności przedsiębiorstwa sprzedaży rzeczy ruchomej osobie fizycznej, która nabyła tę rzecz w celu niezwiązanym z działalnością zawodową lub gospodarczą (art. 1 ustawy $)^{91}$. Do tak zdefiniowanej sprzedaży konsumenckiej nie znalazły już zastosowania przepisy kodeksu cywilnego o rękojmi (art. 4 ustawy).

Dokonane $\mathrm{w}$ prawie polskim zmiany nie ograniczyły się jedynie do modyfikacji podstawy odpowiedzialności sprzedawcy. Ustawa o sprzedaży konsumenckiej z 2003 r. wprowadziła kilka regulacji korzystnych dla obu stron umowy. Przewidziane zostały dłuższe terminy dla dochodzenia przez kupującego uprawnień, uregulowana została kwestia roszczeń zwrotnych sprzedawcy, nabywcom umoż-

${ }^{89}$ Dz.Urz. WE L 171 z 7.07.1999, s. 12. Zob. więcej na temat dyrektywy 1999/44/ WE: J. MaliszewsKa-Nienartowicz, Ochrona konsumenta przed nienależyta jakościa świadczenia w Unii Europejskiej i w Polsce, «MoP» 24/2001, s. 1212-1217.

$90 \mathrm{~W}$ ocenie W.J. KaTnERA, O rękojmi i gwarancji wedtug kodeksu cywilnego i ustawy o sprzedaży konsumenckiej - stów kilka, [w:] Prawo prywatne czasu przemian. Księga pamiatkowa dedykowana Profesorowi Stanisławowi Soltysińskiemu, red. A. Nowicka, Poznań 2005, s. 146, dla określenia odpowiedzialności za niezgodność towaru $\mathrm{z}$ umową można $\mathrm{w}$ dalszym ciągu używać tradycyjnego terminu rękojmia wraz z przymiotnikiem „konsumencka”. Podobną terminologię stosuje M. MolĘDA, Rękojmia i gwarancja jakości a odpowiedzialność cywilna i jej ubezpieczenie, "Wiadomości Ubezpieczeniowe» 9-10/2003, s. 17 i 21.

${ }_{91}$ Zob. M. DrobA, Uwagi o pojęciu sprzedaży konsumenckiej, «Zeszyty Naukowe Uniwersytetu Rzeszowskiego. Seria Prawnicza. Prawo» 3/2005, s. 41-60; M. SKORY, Znaczenie kodeksowej definicji konsumenta dla wyodrębnienia tzw. obrotu konsumenckiego, «Acta Universitatis Wratislaviensis. Przegląd Prawa i Administracji» 64/2004, s. 179-191. 
liwiono uzyskiwanie $\mathrm{w}$ szerokim zakresie informacji o produktach i ich właściwościach poprzez nałożenie na sprzedawców obowiązków informacyjnych.

$\mathrm{Z}$ drugiej jednak strony znacznie obniżony został poziom ochrony konsumenta poprzez wprowadzenie sekwencyjności realizacji przysługujących mu uprawnień i ograniczenie prawa odstąpienia od umowy. Ponadto na negatywna ocenę zasługuje brak wyraźnego określenia procedury reklamacyjnej i wprowadzenie 14-dniowego terminu jedynie w celu zajęcia stanowiska przez sprzedawcę.

Poza wspomnianymi zaletami, podnoszącymi poziom ochrony konsumenta, ustawa o sprzedaży konsumenckiej wprowadziła kilka regulacji pogarszających sytuację kupującego. Takim rozwiązaniem jest przede wszystkim przewidziana $\mathrm{w}$ ustawie sekwencyjność realizacji uprawnień przez nabywcę, połączona z ograniczeniem do minimum możliwości odstapienia przez niego od umowy (art. 8 ustawy). Regulacja ta powszechnie uznana została za „krok wstecz” w porównaniu z przepisami o rękojmi w kodeksie cywilnym ${ }^{92}$. Powoduje ona bowiem, iż konsument pozostaje, jak obrazowo stwierdziła E. Łętowska, „uwięziony” w kontrakcie, który nie spełnił jego oczekiwann ${ }^{93}$. Polski ustawodawca ograniczając się niemal do dosłownego „skopiowania” przepisów dyrektywy 1999/44/WE nie uwzględnił rodzimych realiów

92 E. ŁętowsKa, Prawo umów..., s. 391; K. Szostak, Ochrona kupujacego w świetle nowych regulacji prawnych, «Radca Prawny»16.1/2003, s. 33; J. MaliszewskA-NiENARTOWicz, Sprzedaż konsumencka - wybrane problemy prawne, «Glosa» 12/2002, s. 15; TEJŻE, Ewolucja ochrony konsumenta $w$ europejskim prawie wspólnotowym, Toruń 2004, s. 293; A. BARANowsKa, Uprawnienie do odstapienia od umowy przez kupujacego $w$ świetle nowych regulacji prawnych, «Radca Prawny» 16.5/2003, s. 92; I. KLENIEWSKA, Nowe zasady ochrony konsumenta, «Jurysta» 11-12/2005, s. 5; A. SIKORSKA, Ciężar dowodu w przypadku odstapienia od umowy sprzedaży przez kupujacego z powodu wad rzeczy lub niezgodności towaru z umowq, «Radca Prawny» 18.1/2005, s. 66; Zielona Księga. Optymalna wizja Kodeksu cywilnego w Rzeczypospolitej Polskiej, red. Z. RadWAŃski, Warszawa 2006, s. 115; A. Zawiszowski, Trudno reklamować, «Rzeczpospolita» z 5 września 2006 r.; R. STEFAnICKI, Zgodność towaru z umowa w świetle ustawy o szczególnych warunkach sprzedaży konsumenckiej, [w:] Europeizacja prawa prywatnego, red.: M. PAzDan, W. Popiolek, E. RotT-PIETRzyK, M. SzPUnAR, II, Warszawa 2008, s. 469.

93 E. Łętowska, Prawo umów..., s. 388. 
gospodarczych. W warunkach ciagle niskiej kultury prawnej polskich przedsiębiorców, niechętnych rozpatrywaniu reklamacji, brak wyraźnego uregulowania trybu procedury reklamacyjnej spowodował, iż wiele sporów pomiędzy kupującym a sprzedawcą znajduje rozstrzygnięcie dopiero w sądzie.

Dlatego też wydaje się, iż obowiązujące obecnie jedynie poza obrotem konsumenckim, zasady odpowiedzialności sprzedawcy z tytułu rękojmi lepiej chronią kupującego. Przepisy kodeksu cywilnego w tym zakresie obowiązują już ponad czterdzieści lat, z niewielkimi jedynie zmianami. Zostały one $\mathrm{w}$ tak długim okresie doprecyzowane przez doktrynę i orzecznictwo. Takie terminy jak ,wada rzeczy” czy „rękojmia" zakorzeniły się dość silnie w świadomości zarówno sprzedawców jak i kupujących. Pojęcie niezgodności z umową jest zupełnie nową kategorią, obcą dotychczasowej siatce terminologicznej polskiego języka prawnego. Przyswojenie nowych zwrotów, a przede wszystkim nowych praw i obowiązków jest z pewnością trudne dla obu stron umowy sprzedaży. Ponadto nowe przepisy są nie zawsze jasne i precyzyjne, posługują się często pojęciami otwartymi bądź nieostrymi. Trudne zadanie dookreślenia tych zwrotów przypadnie przedstawicielom doktryny i judykatury.

Consumer Protection at the Turn of the

Century - Warranty in Modern Polish Law

\section{Summary}

The presented article is devoted to development of warranty institution in the Polish modern law. The time frames of this article include the period between 1918 and 2003. The first date marks the beginning of the independent Polish country after the Second World War. The second date is connected with introducing in Poland a new law which implements the European Union directive. This new law concerns consumers and instead of a traditional warranty it introduces a new term of conformity with the contract. 